TITLE:

\title{
Effect of the XIAP inhibitor Embelin on TRAIL-induced apoptosis of pancreatic cancer cells(Abstract_要旨 )
}

$\operatorname{AUTHOR(S):~}$

Mori, Tomohiko

\section{CITATION:}

Mori, Tomohiko. Effect of the XIAP inhibitor Embelin on TRAIL-induced apoptosis of pancreatic cancer cells. 京都大学, 2009, 博士(医学)

ISSUE DATE:

2009-03-23

URL:

http://hdl.handle.net/2433/124345

RIGHT: 


\begin{tabular}{|c|c|}
\hline 京都大学 & \begin{tabular}{l|l} 
氏 名 森 友彦 \\
\end{tabular} \\
\hline 論文題目 & $\begin{array}{l}\text { Effect of the XIAP inhibitor Embelin on TRAIL-induced apoptosis of } \\
\text { pancreatic cancer cells } \\
\text { (膵癌細胞の TRAIL 感受性における XIAP 阻害剤 Embelin の効果について) }\end{array}$ \\
\hline 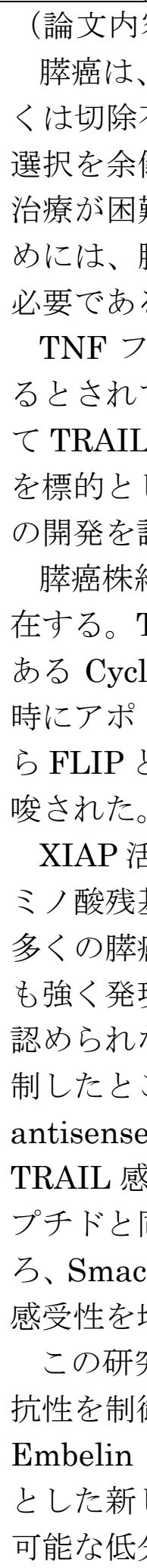 & 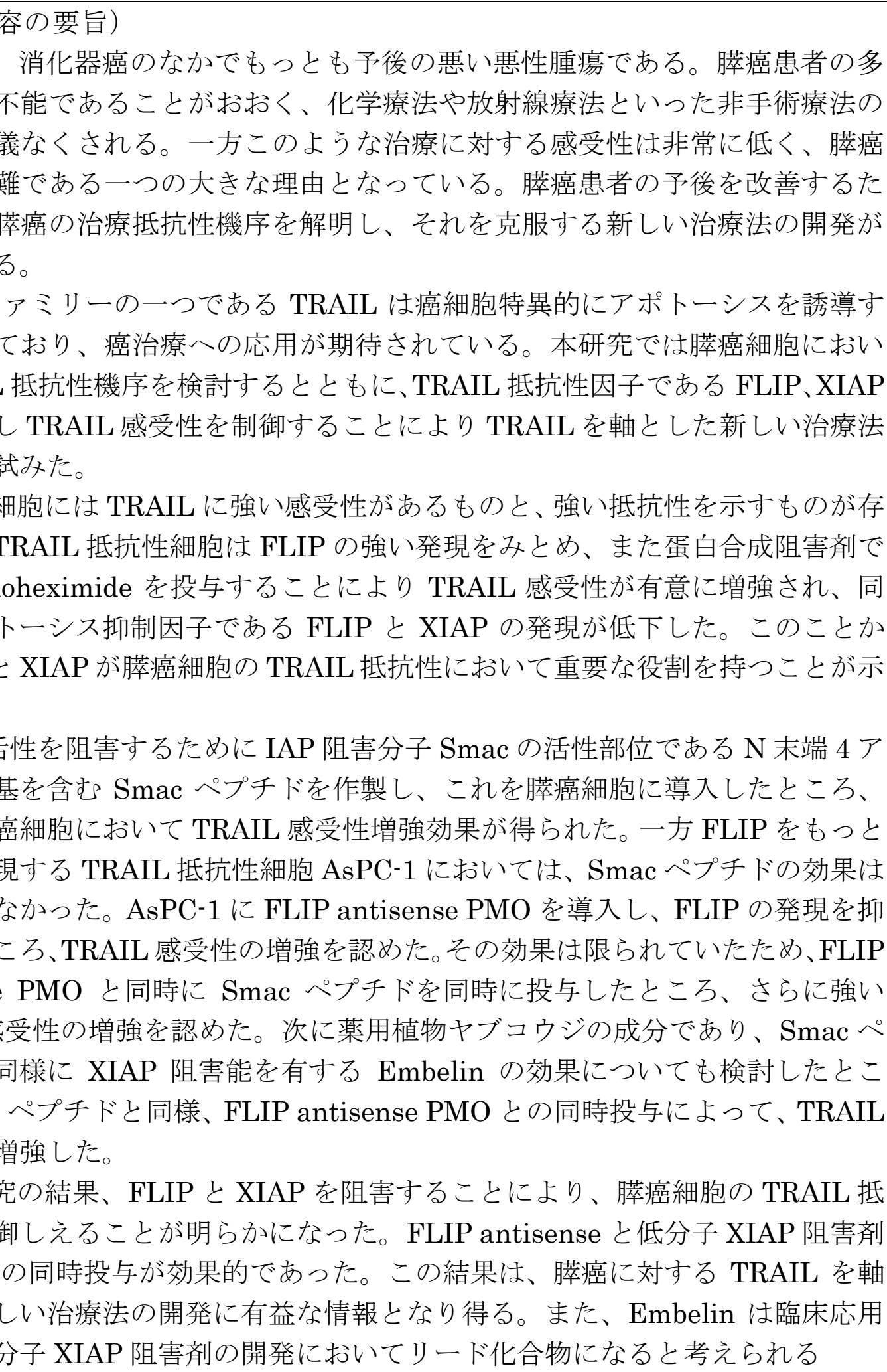 \\
\hline
\end{tabular}

（論文審査の結果の要旨）

膵癌患者の予後を改善するためには、膵癌の治療抵抗性の機序を解明し、それを克服す る新しい治療法の開発が必要である。TRAILは癌細胞特異的にアポトーシスを誘導するこ とが知られており、癌治療への応用が期待されている。本研究では、膵癌細胞における TRAIL抵抗性機序の解明とTRAILを軸とした新しい治療法の開発が試みられた。 TRAIL抵抗性膵罍細胞株にCycloheximideを投与することによりTRAIL感受性が有意に 増強され、同時にFLIPとXIAPの発現が低下した。Smacペプチドを膵癌細胞に導入し、 XIAP活性を阻害することにより、多くの膵癌細胞においてTRAIL感受性増強効果が得ら れた。

FLIPを強く発現するAsPC-1細胞株にFLIP antisense PMOを導入したところ、

TRAIL感受性の増強をみとめ、さらにSmacペプチドを同時に投与したところ、さらに強 いTRAIL感受性増強を認めた。XIAP阻害能を有するEmbelinの効果についても検討した が、FLIP antisense PMOとの同時投与によって、TRAIL感受性は増強した。これら の結果、FLIPとXIAPを阻害することにより、膵癌細胞のTRAIL抵抗性を制御しえること が明らかになった。

以上の研究は膵癌細胞のTRAIL抵抗性機序を解明し、膵癌治療の発展に寄与寸るところが 多い。

したがって、本論文は博士(医学)の学位論文として価值あるものと認める。 なお、本学位授与申請者は、平成 21 年 3 月 9 日実施の論文内容とそれに関連した研究分野並 びに学識確認のための試問を受け、合格と認められたものである。 